\title{
КОМПЛЕКС МЕТОДОВ ХИМИЧЕСКОГО АНАЛИЗА ДЛЯ РЕШЕНИЯ АКТУАЛЬНЫХ НАУЧНЫХ ЗАДАЧ В АНАЛИТИЧЕСКОЙ ЛАБОРАТОРИИ ИНХ СО РАН

\author{
Сапрыкин А.И. ${ }^{1,2}$
}

${ }^{1}$ ФББУН Институт неорганической химии им. А.В. Николаева СО РАН, Новосибирск, Россия

${ }^{2}$ Новосибирский национальный исследовательский государственный университет, Новосибирск, Россия

saprykin@niic.nsc.ru

DOI: 10.26902/ASFE-11_01

24.07.2020 г. исполнилось 100 лет со дня рождения доктора химических наук, профессора И.Г. Юделевича, создателя и первого руководителя Аналитической лаборатории ИНХ СО РАН. Его роль в становлении и развитии комплекса методов анализа высокочистых и функциональных материалов в Новосибирском научном центре трудно переоценить. При создании лаборатории основной акцент был сделан на оснащении лаборатории комплексом инструментальных методов определения химического состава такими как атомно-эмиссионная, атомно-абсорбционная и масс-спектрометрия. Особое внимание руководством Института уделялось привлечению выпускников химического и физического факультетов НГУ для работы на современном оборудовании и подготовке квалифицированного персонала химиков-аналитиков. Результатом этой деятельности явилось создание сплоченного коллектива единомышленников: специалистовпрофессионалов и талантливых молодых ученых, постоянный приток которых обеспечивал принцип взаимопомощи и преемственности. Под руководством профессора Юделевича было подготовлено и защищено более 40 кандидатских диссертаций, пятеро его учеников стали докторами наук.

Одним из основных направлений деятельности лаборатории стала разработка т.н. комбинированных методик КХА, основанных на сочетании различных приемов отделения основы и концентрирования примесей с современными инструментальными методами, что позволило существенно расширить их аналитические возможности и решить ряд уникальных задач в сфере контроля чистоты полупроводниковых материалов и получения высокочистых веществ. Одновременно профессор Юделевич явился инициатором расширения сферы деятельности лаборатории в направлении, ориентированном на исследование химического состава природных и биологических объектов, развитию методов не только высокочувствительного элементного, но и вещественного анализа.

По инициативе и под руководством И.Г. Юделевича было создано Сибирское отделение Научного совета по аналитической химии, а организованный им Новосибирский аналитический семинар приобрел широкую известность и сыграл значительную роль в повышении квалификации специалистов заводских лабораторий и НИИ. В работе семинара принимали участие не только аналитики Новосибирского Научного Центра, но и различных предприятий и организаций Сибири, Дальнего востока и Европейской части страны. Конференция «Аналитика Сибири», которая переросла региональные рамки и приобрела масштаб Всероссийского форума, также стартовала по инициативе И.Г. Юделевича.

Сегодня аналитическая лаборатория входит в Центр коллективного пользования ИНХ СО РАН и регулярно получает, и осваивает новое аналитическое оборудование и принимает на работу молодых специалистов, что позволяет ей хранить традиции и с оптимизмом смотреть в будущее.

Работа выполнена в рамках государственного задания ИНХ СО РАН в области фундаментальных научных исследований, проект № 121031700315-2. 